Poznań

\title{
10 lat członkostwa Polski w Unii Europejskiej - próba bilansu z perspektywy politologicznej
}

\begin{abstract}
Wstęp
Jubileusz 10 lat akcesji Polski do Unii Europejskiej skłania do interdyscyplinarnej debaty, czynienia bilansów korzyści i strat, podsumowań związanych z aktywnością Polski na arenie europejskiej. Wśród pojawiających się publicystycznych, jak i naukowych opracowań poświęconych temu zagadnieniu, odnotować należy te, które oceniają członkostwo Polski w UE przez pryzmat zmian krajowego systemu koordynacji polityki europejskiej, poziomu absorpcji środków pochodzących z funduszy strukturalnych, sposobu ich wykorzystania. Nie mniej zajmujące są analizy poświęcone aktywności polskich deputowanych do Parlamentu Europejskiego oraz prawne, opisujące pozycję Polski w strukturach wspólnotowych, wynikającą z aktualnie obowiązujących traktatów. Barw analizie nadaje dyskurs o udziale naszego kraju w antykryzysowej debacie europejskiej, o staraniach Polski o utrzymanie proinwestycyjnego charakteru unijnego budżetu, analiza dyskursu politycznego na temat Polski w Unii, przyszłości integracji europejskiej w ogóle. Interesujących wniosków na temat statusu członkowstwa Polski w UE dostarcza ocena pierwszego polskiego przewodnictwa w Radzie Unii Europejskiej.

Celem opracowania jest wskazanie najważniejszych zdaniem autora, wydarzeń charakteryzujących członkostwo Polski w Unii Europejskiej. Autor dokona ich systematyzacji, opisu, a także podziału na wydarzenia europejskie mające wpływ na bieg spraw krajowych i na te krajowe, które cechowały polską dyplomację europejską w ostatniej dekadzie. Autor wskaże cechy charakterystyczne dwóch dyskursów o polskiej polityce europejskiej, które już od referendum akcesyjnego, przez kolejne lata członkostwa w UE angażują uwagę Polek i Polaków wokół spraw unijnych. Na tej podstawie zostaną nakreślone kierunki polskiej polityki europejskiej w perspektywie kolejnych lat członkostwa w UE. Można przypuszczać, że różnice między dwoma dużymi partiami co do sposobu i celów prowadzonej polityki europejskiej będą się pogłębiały. Różnice te będą coraz bardziej wydatne, ze względu na agendę spraw unijnych do rozwiązania w najbliższych latach. Od tego w jaki sposób Polakom zostanie przedstawiona polityka europejska, zależeć będzie poparcie dla idei integracji europejskiej, które pomimo tego, że w dalszym ciągu jest wysokie, może drastycznie spadać.
\end{abstract}

\section{Krajowa perspektywa}

Perspektywa dziesięciu lat członkostwa to wystarczający okres dla poczynienia głębszej analizy i wyprowadzenia prawidłowości. Nie sposób nie dostrzec jakże ciekawego 
okresu w życiu politycznym Unii Europejskiej, w którym nasz kraj, nasi przedstawiciele, mogli brać udział. To także niewątpliwie ciekawy okres w wewnątrzkrajowym życiu politycznym, którego rytm wyznaczały konsekwencje wyborów parlamentarnych i prezydenckich z lat 2005, 2007, 2010, 2011.

W życiu Unii Europejskiej mogliśmy obserwować dwa podejścia do zmiany traktatowej, próbę systematyzacji integracji poprzez jej konstytucjonalizację i dekonstytucjonalizację, negocjacje i wprowadzanie w życie nowej perspektywy finansowej na lata 2007-2013 czy też zmagania Unii z szeroko pojętym bezpieczeństwem energetycznym, kryzysem zadłużeniowym, nowym rozdaniem instytucjonalnym, Wieloletnimi Ramami Finansowymi 2014+i in.

Warto zauważyć, iż elementem pozwalającym na kształtowanie polityki europejskiej jest system koordynacji. W ogólnej unijno-krajowej architekturze nabiera się przekonania o tym, jakże ważnym elementem wzmacniającym członkostwo jakiegokolwiek państwa w UE, jest sprawnie działający system koordynacji polityk europejskich. Polski system koordynacji kształtował się już w okresie przedakcesyjnym w ramach Komitetu Integracji Europejskiej i Urzędu Komitetu Integracji Europejskiej. W okresie pierwszych lat po akcesji ów system był poddany silnemu oddziaływaniu europejskich doświadczeń integracyjnych. Kształtował się również w oparciu o doświadczenia płynące ze współpracy z innymi państwami członkowskimi i ich systemami koordynacji polityki europejskiej. Zasadniczej zmiany systemu dokonano na skutek przygotowań Polski do Przewodnictwa w Radzie Unii Europejskiej oraz zmiany traktatów podstawowych, do których należało dostosować polskie rozwiązania.

Podsumowując dzisiaj polskie doświadczenia członkostwa w Unii Europejskiej należy mieć na względzie, iż w momencie akcesji atmosfera polityczna po stronie UE-15 daleka była od tej towarzyszącej państwom przystępującym do UE. Aktualny Przewodniczący Parlamentu Europejskiego wskazywał na obawy związane ze stabilnością demokracji w tej części Europy. Ponadto w gronie UE-15 zadawano pytanie o to w jakim tempie nowi członkowie „,nauczą się” integracji (Press Office EP). Złożyło się na to przynajmniej kilka czynników. Warto przypomnieć, że w UE trwała wówczas niedokończona już od 1995 roku reforma traktatowa, która miała odpowiedzieć na szereg pytań związanych z rozszerzeniem. Wśród nich było pytanie o zasady akcesji, które de facto sprowadzały się do zasadniczych kwestii związanych ze sposobem podejmowania decyzji w Radzie UE, kształtem unijnego systemu decyzyjnego, liczbą posłów i uprawnieniami kodecyzyjnymi Parlamentu Europejskiego, podziałem środków budżetu europejskiego, uwspólnotowieniem nowych obszarów polityki krajowej i in. Obrazem dla tych dylematów były kolejno Traktat amsterdamski, Traktat nicejski, ustanawiający konstytucję dla Europy.

Entuzjazm integracyjny po stronie UE-15 w przededniu akcesji gasiły: trwająca reforma traktatowa, (konferencja międzyrządowa), zbliżające się wybory do PE, zmiana na arenie międzynarodowej związana z podziałem UE na państwa stojące po stronie USA w walce $\mathrm{z}$ terroryzmem i na te, które do walki z terrorystami szukały silniejszego mandatu ONZ.

Z kolei w Polsce poparcie dla integracji z Unią Europejską było niezmiennie wysokie. 
Wykres 1. Poparcie dla integracji europejskiej wśród osób deklarujących udział w referendum akcesyjnym [w \%]

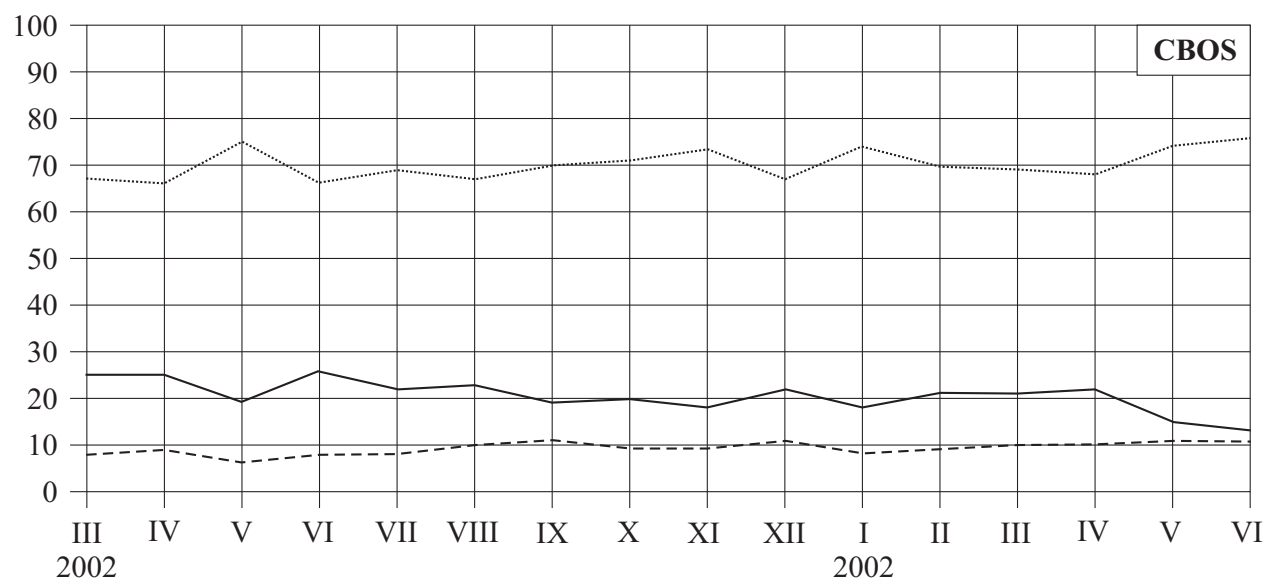

Czy będzie Pan(i) głosować:

……........ za przystapieniem Polski do Unii Europejskiej;

— przeciw przystapieniu Polski do Unii Europejskiej;

----- trudno powiedzieć.

Do sondażu z maja 2003 r. pytanie brzmiało: „Czy w referendum głosował(a)by Pan(i):”.

Wyniki referendum pozwoliły Prezydentowi RP na ratyfikację Traktatu akcesyjnego i z dniem 1 maja 2004 zakończył się okres przygotowań akcesyjnych, a Polska stała się pełnoprawnym członkiem UE.

$\mathrm{Z}$ chwilą akcesji, a także w trakcie prowadzonych negocjacji akcesyjnych Polska uchodziła za lidera, bez którego rozszerzenie nie byłoby możliwe. Oczywiście stwierdzić należy, że były momenty, w których sugerowano, że rozszerzenie bez Polski jest możliwe, ale wydaje się, że była to raczej pewna taktyka negocjacyjna aniżeli na poważnie rozważana ewentualność na wypadek przeciagających się negocjacji. Tak to ujmuje w specjalnym raporcie przedakcesyjnym opracowanym na zlecenie R. Prodiego, Wim Kok. „Niekiedy pojawia się pytanie „Jaki byłby koszt, gdyby do rozszerzenia UE nie doszło?". Czy można obliczyć jakie byłyby konsekwencje, jeżeli UE nie przeprowadziłaby planowanego rozszerzenia - tak jak w przeszłości obliczano koszty sytuacji, gdyby UE nie utworzyła jednolitego rynku? Te dwa przypadki są różne. Rozszerzenie UE jest procesem trwającym od ponad dziesięciu lat, który już przyniósł rezultaty; niewykonalne jest „cofnięcie wskazówek zegara”. Ponadto, powody dla rozszerzenia nie są jedynie gospodarcze, ale również polityczne, i dlatego trudno je zmierzyć. Jednak pytanie to zasługuje na odpowiedź Zobowiązuje nas do zrewidowania rezultatów i perspektyw procesu rozszerzenia.

Co zostało dotychczas osiagnięte?

- Perspektywa przystapienia do UE przyśpieszyła proces transformacji w Europie Środkowo-Wschodniej, który nastąił po upadku komunizmu.

- Pojawienie się tam stabilnych demokracji poprawiło bezpieczeństwo w Europie jako całości. Przyczyny konfliktów, takich jak kwestie mniejszościowe i problemy nadgraniczne zostały usunięte. 
- Szybki wzrost w handlu oznacza nowe rynki i inwestycje dla członków UE: dla przyszłych członków UE jest już obecnie najważniejszym partnerem handlowym. Bez projektu rozszerzenia UE, wiele z tych korzyści nie byłoby osiagniętych" (Kok, 2003).

Okres dziecięciu lat członkostwa w Polsce podzielić można na kilka podokresów. Rytm tej dekadzie nadawały konsekwencje kryzysu rządowego z 2004 roku, wyniki wyborów parlamentarnych i prezydenckich z 2005 roku, przyspieszonych wyborów parlamentarnych z 2007 roku, przyspieszonych prezydenckich z 2010 roku, parlamentarnych z 2011 roku, przygotowania do polskiego przewodnictwa w UE w II poł. 2011 roku. W analizowanym okresie polski dyskurs europejski charakteryzowała retoryka oparta na przynajmniej dwóch scenariuszach członkostwa w Unii. Jej korzeni należy szukać już w argumentacji przedstawianej przez partie polityczne podczas kampanii przed referendum akcesyjnym w 2003 roku. Dwie największe partie polityczne rządzące Polską w ostatniej dekadzie charakteryzuje odmienna wizja członkostwa Polski w UE. W kampanii przed referendum Prawo i Sprawiedliwość koncentrowało swój przekaz wokół słów: Silna Polska w Europie. W partii zwyciężyła wówczas optyka popierająca integrację. Zwrócono uwagę chociażby na to, że będąc w Unii będziemy mieli wpływ na to, co Polski dotyczy. Jeśli byśmy się wyrzekli Unii, to byśmy się wyrzekli wpływu na własne sprawy. To byłaby decyzja całkowicie niesłuszna. Chcąc lepiej zrozumieć upór polskiej delegacji co do kształtu Traktatu lizbońskiego warto pamiętać, że PiS z entuzjazmem odbierał nicejskie warunki członkostwa uznając, że odnieśliśmy sukces w rokowaniach dotyczących politycznej pozycji Polski w UE. W związku z tym możemy skuteczniej walczyć o swoje interesy. Definiując akceptowalną dla PiS formę integracji wskazywano, iż należy uznawać zasadę, że tylko suwerenne państwo polskie, zakorzenione od wieków w kulturze i tradycji chrześcijańskiej, jest skutecznym narzędziem realizacji aspiracji politycznych, gospodarczych, społecznych i kulturalnych narodu i jedynie ono jest w stanie zapewnić Polakom realne możliwości korzystania z praw i wolności obywatelskich oraz dobrodziejstw systemu demokratycznego. Dlatego Polska nie może zaakceptować w żadnej formie przekształcenia UE w federację znoszącą lub istotnie ograniczającą rolę członkowskich państw narodowych ${ }^{1}$. Partia Jarosława Kaczyńskiego sprawowała w Polsce rządy w latach 2005-2007. W tym okresie Polska na szczeblu unijnym musiała współdecydować w sprawie wieloletniego budżetu UE do 2013 roku, o kształcie nowego unijnego traktatu. Zainicjowano powstanie unijnej polityki energetycznej jako jednej z zewnętrznych polityk UE, która docelowo miała pozwolić na dywersyfikację zaopatrzenia UE w gaz, dywersyfikację surowców energetycznych, a także pomoc $\mathrm{w}$ walce $\mathrm{z}$ nadmierną emisją $\mathrm{CO}_{2}$. W zakresie polityki zagranicznej polski Prezydent próbował zainteresować Unię wschodnią flanką, angażując się na rzecz rozwiązania konfliktu gruzińskiego. Lech Kaczyński wykazał inicjatywę budowy koalicji państw środkowoeuropejskich wspierających Gruzję i inne państwa w ich polityce rosyjskiej. Piotr Semka charakteryzuje to przez pryzmat wierności „tradycji piłsudczykowskiej [która - przyp. M.T.] wysunęła na czoło nową poli-

1 Szerszej charakterystyki stanowiska PiS ws. integracji należy szukać w: Silna Polska w Europie, Uchwała nr 1/06/03, Rada Polityczna PiS, Warszawa 2003; Polska katolicka w chrześcijańskiej Europie, Program PiS, Warszawa 2005. 
tykę wschodnią - popieranie sojuszu GUAM ${ }^{2}$ - Gruzja, Ukraina, Azerbejdżan i Mołdowa. Chęć związania z Polską krajów, które w historii były dla Polski ważne. To cel związany z bezpieczeństwem energetycznym, poszerzeniem Unii Europejskiej i NATO. Działania zmierzające do zmiany na polską korzyść układu sił w tych organizacjach, czy też ograniczenia imperialnych zapędów niektórych naszych sąsiadów" (Semka, 2010, s. 259). Stąd też lata 2005-2007 (pod pewnymi warunkami do 2010 roku) scharakteryzować można jako czas konsekwentnej polityki europejskiej uznającej za swe priorytety:

- traktowanie NATO jako podstawowej instytucji gwarantującej bezpieczeństwo Europy;

- zachowanie określonej w Traktacie nicejskim pozycji Polski w Unii Europejskiej;

- utrzymanie zasady jednomyślności przy wprowadzaniu jakichkolwiek zmian w traktatach Unii Europejskiej;

- nienaruszalność suwerenności Rzeczypospolitej w polityce zagranicznej;

- zachowanie niezależności w ramach wspólnego rynku - polskiej polityki gospodarczej;

- zachowanie w polityce regionalnej zasady solidarności finansowej (Semka, s. 259 i nast.).

Pomimo wielu starań zarówno w okresie negocjacji akcesyjnych, jak i po rozszerzeniu, Polsce nie udało się, z wielu przyczyn, zbudować silnych więzów integracyjnych pomiędzy państwami w tej części kontynentu. Wysiłek ten był podjęty w ramach Grupy Wyszehradzkiej, ale dość wcześnie okazało się, że zarówno Republika Czeska, Republika Słowacja i Węgry zasadnicze sprawy europejskie załatwiają z pominięciem Warszawy. Ten stan utrzymał się również po akcesji np. przy próbie budowy koalicji pierwiastkowej, przy konsolidacji stanowiska ws. unijnego budżetu czy też przy negocjacjach pakietu klimatycznego UE. Raport rządowy stwierdza: „Jednym z największych powodów do satysfakcji po 10 latach w Unii Europejskiej może być bardzo dobry bilans współpracy Polski, Czech, Słowacji i Węgier w ramach Grupy Wyszehradzkiej, która wyrosła na najbardziej prężne regionalne ugrupowanie w Unii”" (Raport MSZ, s. 31). Pomimo tego przekonania, warto zauważyć, że konsolidacja interesów europejskich Europy Środkowej i Wschodniej w ramach Grupy Wyszehradzkiej nie wytrzymuje najważniejszych spraw dla całej Unii. Zwrócić należy uwagę chociażby na niespójne stanowiska członków V4 w kontekście reakcji UE na kryzys na Ukrainie. Ponadto, każde z tych państw na swój sposób szukało wyjścia z zapaści kryzysowej nawiązując sojusze gospodarcze nawet wbrew przyjętej unijnej logice.

W wyniku przedterminowych wyborów parlamentarnych na jesieni 2007 roku ster rządów w Polsce przejęła Platforma Obywatelska. Partia ta w okresie przedakcesyjnym opowiadała się za członkostwem Polski w UE, definiując swoje hasło referendalne Europa to nasza szansa. Polska to nasz dom. Zachęcając do akcesji skoncentrowano się na

2 GUAM - skrót powstałego w 1999 sojuszu Gruzji, Ukrainy, Azerbejdżanu i Mołdowy zawiązanego wokół niepokoju związanego z możliwością umocnienia rosyjskich kontyngentów wojskowych w tych państwach. Cel działania organizacji: zacieśnienie wzajemnej współpracy gospodarczej w ramach powołania strefy wolnego handlu oraz prowadzenia polityki bezpieczeństwa energetycznego. 
polskim statusie w UE, polityce rolnej, wymianie młodzieży, pogłębianiu integracji w ramach rynku wewnętrznego $i$ in. W okresie rządów tej partii premierem był Donald Tusk, zaś ministrem spraw zagranicznych Radosław Sikorski. Ministrami ds. europejskich byli kolejno Mikołaj Dowgielewicz, Piotr Serafin. W rządzie Ewy Kopacz ministrem spraw zagranicznych jest Grzegorz Schetyna, zaś ministrem ds. europejskich jest Rafał Trzaskowski. W okresie tym nasz kraj intensywnie przygotowywał się do sprawowania pierwszego przewodnictwa w Radzie Unii Europejskiej, negocjowano kształt unijnej polityki klimatycznej, przyjęto Traktat lizboński oraz pakt stabilizacyjny jako instrument antykryzysowy. Polska była czynnym uczestnikiem debaty o sposobach wyjścia UE z kryzysu, stała na czele koalicji państw przyjaciół polityki spójności, podniosła swój kapitał relacyjny, mając wpływ na obsadę ważnych stanowisk unijnych np. Przewodniczącego Parlamentu Europejskiego czy też ostatnio Przewodniczącego Rady Europejskiej. W ramach kontynuacji polityki wschodniej zaproponowano tzw. Partnerstwo Wschodnie oraz podjęto próby pokojowego rozwiązania konfliktu ukraińsko-rosyjskiego. Na okres 2007-2014 przypadły lata zasadniczej absorpcji środków unijnych zarówno na szczeblu centralnym, jak i regionalnym. Polska polityka europejska starała się odzwierciedlać nowy model odejścia od tzw. Jagiellońskiej polityki zagranicznej na rzecz piastowskiej polityki opartej na umacnianiu swej pozycji w strukturach unijnych przy zachowaniu dobrych relacji ze Stanami Zjednoczonymi Ameryki.

W swoim pierwszym expose premier Donald Tusk, podejmując tematykę członkostwa Polski w Unii Europejskiej, apelował o odejście od polityki wąsko partyjnych interesów i doktrynerskich sporów na rzecz, ,[...] polityki solidarności w sprawach międzynarodowych tutaj i solidarności w wymiarze międzynarodowym, potrzebny jest możliwie szeroki dialog społeczny. [...] Polityka międzynarodowa nie może być i nie będzie zakładnikiem wąskopartyjnych interesów i doktrynerskich sporów" (Expose, 2007). Kreśląc scenariusz przyszłości integracji europejskiej premier odwołując się do polityki realizowanych interesów narodowych wskazał, iż „,...] Chcemy wewnątrz Unii Europejskiej realizować polskie interesy, ale chcemy także, i to jest zadanie bardzo ambitne, prezentować polską wizję dalszego rozwoju całej Unii Europejskiej. Wierzymy bowiem, [...], że pogłębienie współpracy w ramach Unii oraz jej rozszerzanie są żywotnym interesem całej wspólnoty unijnej, ale także Polski. Unia Europejska nie jest superpaństwem i nie będzie superpaństwem, ale powinna być supermocarstwem, powinna być tą organizacją, a my ważnym jej członkiem, która jest respektowana, szanowana na całym świecie i która jest głównym, podstawowym aktorem zdarzeń globalnych. To jest ambitny zamiar, a my, Polacy, mamy prawo i obowiązek te aspiracje kształtować. Polska nie była i na pewno nie będzie kopciuszkiem w Unii Europejskiej. Polska będzie kluczowym aktorem na scenie europejskiej, a co za tym idzie - na scenie światowej. Silna Unia to Unia zintegrowana, to Unia zbudowana na solidnych podstawach, a solidne podstawy to wspólne wartości" (Ibidem). W dalszej części wystąpienia premier zapowiedział przywrócenie dobrych relacji nie tylko z Unią, ale również z jej poszczególnymi państwami. Zapowiedział odnowienie strategicznych relacji z Niemcami i z Francją. „Chcemy zintensyfikować współdziałanie z Niemcami i Francją, bo jak do tej pory, tak i w przyszłości, wtedy kiedy relacje między Warszawą, Berlinem a Paryżem są dobre, to dobrze realizujemy polski interes w Unii Europejskiej. Polski rząd, 
mój rząd, jest gwarancją dobrego współdziałania z kluczowymi partnerami w ramach Unii Europejskiej" (Ibidem).

W ślad za tymi deklaracjami nastapiły czyny. Polska w grudniu podpisała Traktat lizboński ${ }^{3}$, który następnie poddano ratyfikacji we wszystkich państwach członkowskich, w I kwartale 2008 zintensyfikowano przygotowania do polskiej prezydencji, podjęto temat negocjacji pakietu klimatycznego UE, nakreślono nowy plan dla polityki wschodniej. Nowym elementem polityki zagranicznej był fakt koabitacji. Pomimo wielu wspólnych punktów widzenia o relacje na linii Prezydent RP Szef Rady Ministrów doczekały się określenia mianem, dziwnych, niezrozumiałych, wzajemnych fobii, przemysłu pogardy, sporu o krzesło, sporu o samolot, urażonej dumy i in. W konsekwencji ów spór dotknął konstytucyjnych uprawnień Prezydenta RP w sprawach związanych z polityką zagraniczną i polityką europejską. Opisując te relacje i realizowaną przez D. Tuska politykę europejską śp. Lech Kaczyński powiedział ,[...] byłbym w stanie powiedzieć jedynie, że głównym celem rządu Platformy jest, aby Polska była powszechnie kochana. Tylko, że nie wiadomo po co" (Warzecha, s. 251). Wskazując na porażki rząqu PO w polityce europejskiej:

- budowę gazociągu Nord Steam;

- powstanie w Berlinie Centrum „Widoczny Znak”;

- niepowstanie we Wrocławiu Europejskiego Instytutu Technologicznego we Wrocławiu, lecz na Węgrzech;

- niekorzystna dla polskiej gospodarki opartej na węglu sprawa ograniczeń emisji dwutlenku węgla;

- niewejście do grupy państw G-20;

- totalna porażka polityki na wschodzie Europy;

- wpisywanie się Donalda Tuska i jego partyjnych kolegów w rosyjską politykę historyczną;

- niski udział Polaków w kadrach europejskiej dyplomacji (Por. Warzecha, s. 252).

Dużym wyzwaniem politycznym, jak i organizacyjnym była polska prezydencja w Radzie Unii Europejskiej. W raporcie rządowym podsumowującym 10 lat członkostwa w Unii Europejskiej czytamy, że prezydencja służyła skutecznej obronie metody wspólnotowej, spójności i integralności UE, zapobieżeniu podziałowi Unii, którego ryzyko wynikało z kryzysu. Dla Polski prezydencja była inwestycją w skuteczniejszą realizację interesów Polski w kolejnych latach (Raport MSZ, s. 35 i 36). Analizując polskie przewodnictwo z punktu widzenia realizacji zakładanych priorytetów, które wynikały w pierwszej kolejności z kalendarza prac legislacyjnych UE i naszych aspiracji należy odnotować wypracowanie porozumienia wokół tzw. sześciopaku, sprawne negocjacje budżetowe na rok 2012, wypracowanie porozumienia ws. zasad jednolitego patentu, podpisanie traktatu akcesyjnego z Chorwacją $i$ tym samym potwierdzenie roli Polski jako przyjaciela rozszerzenia UE, uzgodnienie pakietu dyrektyw i rozporządzeń w ramach tzw. zewnętrznego wymiaru polityki energetycznej i in. Było to przewodnictwo opowiadające się jednoznacznie za pogłębieniem integracji europejskiej, a nie fragmentacją - solidarność europejska, co ważne w kontekście polityki spójności. Ponadto

3 Wynegocjowany przez rząd PiS i Prezydenta RP Lecha Kaczyńskiego. 
polska dyplomacja starała się pilnować, aby w kontekście mechanizmu antykryzysowego zastosowano zasadę partizipating not voting (Tomaszyk, s. 230).

Wśród negatywnych ocen formułowanych przez opozycyjne środowisko krajowe wymienić należy fakt, iż była to prezydencja dobrze zarządzająca procesem decyzyjnym zamiast prezydencji kreującej nowe pola polityki. Ponadto w odniesieniu do Traktatu o unii fiskalnej i europejskim mechanizmie stabilności, polska prezydencja była na poziomie narracji, a nie faktów. Często jednak negatywne opinie o prezydencji są formułowane w oparciu o oczekiwania odpowiadające realiom nicejskiego, a nie lizbońskiego modelu przewodnictwa w RUE. Były to oczekiwania słuszne, jednak nieuwzględniające zmiany traktatu tym samym stawały się niemożliwe do spełnienia (Tomaszyk, 2012, s. 230).

Polskie przewodnictwo w Radzie UE zbiegło się w czasie z opracowywanym na szczeblu unijnym modelem antykryzysowej integracji całej lub części Unii oraz z pracami nad strategicznym dokumentem Europa $2020 \mathrm{i}$ kompatybilnym z nim wieloletnim budżetem UE - Wieloletnimi Ramami Finansowymi. Zadanie naszego rządu polegało na tym by w II połowie 2011 roku rozpocząć polityczną debatę o konkretnych środkach przeznaczonych na rozwój unijnych polityk. Zadanie to musiało uwzględniać wiele czynników utrudniających wywiązanie się z niego w oczekiwanym terminie. Zaliczyć do nich należy chociażby aktualną do dnia dzisiejszego retorykę wskazującą na to, że unijny budżet powinien być skromniejszy o kwoty przeznaczone na ratowanie gospodarek pogrążonych w kryzysie. Podział na państwa płatników netto i państwa najwięcej transferujących z wieloletniego budżetu jasno pokazywał, w jaki sposób środki budżetowe mogą wspomagać walkę ze zróżnicowaniem regionalnym, ale również jakim obciążeniem mogą być dla państw bardziej rozwiniętych. Koalicja państw najwięcej dopłacających do unijnego budżetu, motywowana chociażby już wypłaconą pomocą w ramach Europejskiego Mechanizmu Stabilizacyjnego, była zainteresowana poczynieniem w unijnym budżecie rekompensaty za wypłacone środki. Pomimo tego, że wysokość rekompensaty była minimalna w skali środków już wypłaconych, to sam fakt jej pozyskania pozwolił na wykazanie się przed społeczeństwem prowadzoną polityką oszczędności (Tomaszyk, s. 219).

Po drugiej stronie unijnego stołu negocjacji budżetowych w Radzie UE zasiedli przedstawiciele państw, które przez ostatnie lata uzależniły się od środków europejskich i dzięki nim podejmowali ważne inwestycje infrastrukturalne, gospodarcze, społeczne, wykazując przed swoimi wyborcami zaradność i umiejętność walki o środki, które w solidarnej Europie im się należą. Zestawienie tych dwóch narracji rodziło zasadne obawy, że w efekcie kryzysu mamy do czynienia z wyczerpaniem się narracji pro integracyjnej, gdyż każda ze stolic „,chce ugrać” na Europie jak najwięcej dla siebie, a UE i jej instytucje są dobrym wythumaczeniem jakichkolwiek niepowodzeń w tym zakresie. Prace polskiej dyplomacji utrudniał również kalendarz wyborczy m.in. we Francji i w Niemczech. Polska dyplomacja koncentrowała uwagę na korzystnym dla Polski budżecie unijnym również niezależnie do sprawowanej prezydencji. Warto wspomnieć chociażby o spotkaniu grupy państw przyjaciół polityki spójności w Pradze w 2012 roku, spotkanie w Bratysławie i wspólne komunikaty np. ten związany z kwalifikowalnością środków unijnych (Raport MSZ, s. 30). W rządowym Raporcie podsumowującym 10 lat członkostwa w UE wskazuje się m.in. na awans polityczny naszego 
kraju w Unii Europejskiej, uzyskanie silnej pozycji i reputacji kraju przewidywalnego i odpowiedzialnego, skuteczne budowanie koalicji i prowadzenie polityki charakteryzowanej jako polityka gry zespołowej (Raport MSZ, s. 10-12). Z całą pewnością dla lepszej pozycji naszego kraju w UE nie bez znaczenia pozostała przynależność polskiej partii rządzącej i jej posłów do Parlamentu Europejskiego do największej frakcji parlamentarnej - Europejskiej Partii Ludowej. Warto jednak pamiętać, że nie mniejsze znaczenie dla skutecznej reprezentacji Polski w Unii Europejskiej ma silna, na wysokim urzędniczym szczeblu reprezentacja w unijnych instytucjach. Warto wspomnieć, że to m.in. na wniosek Polski urząd rekrutujący pracowników do pracy w unijnej administracji - EPSO-zmienił zasady rekrutacji, które w większym stopniu miały oddawać równowage geograficzną całej Unii. Jednak w dalszym ciągu na ponad 2400 urzędników z Polski zatrudnionych w instytucjach unijnych, na KE przypada 1421, z czego połowa zajmuje stanowiska urzędnicze, a tylko 10 osób kierownicze. Tylko 113 osób spełnia wymogi potrzebne do zajmowania stanowisk kierowniczych. Zaś w Parlamencie Europejskim pracuje 395 Polaków, z czego większość to asystenci poselscy, w Radzie UE pracuje 110 osób, zaś w Radzie Europejskiej tylko jedna osoba pracuje w gabinecie Przewodniczącego (Polityka Inside, 2014). Ten przegląd unijnych instytucji pokazuje, że państwa o dłuższej tradycji członkostwa mają większy zasób kadrowy związany ze stanowiskami kierowniczymi. To co jest naturalną sprawą związaną z awansem zawodowym, musi być wspomagane przez rząd państwa członkowskiego np. poprzez popularyzację pracy w unijnym zasobie kadrowym.

\section{Perspektywa europejska}

Czynnikami zewnętrznymi mającymi niewątpliwe znaczenie dla pozycji Polski w UE były: porażka traktatu konstytucyjnego, okres refleksji pokonstytucyjnej, prezydencja w UE RFN w 2007 roku i wypracowanie Traktatu lizbońskiego, ratyfikacja Traktatu lizbońskiego, jego wejście w życie, negocjacje budżetowe z 2006 i 2013 roku, kryzys integracyjny będący skutkiem zapaści gospodarczej państw PIGS, wybory do PE z 2004 i 2009 roku. Nie mniejsze znaczenie dla priorytetów polskiej dyplomacji miały wydarzenia w Gruzji i na Ukrainie związane z nową polityką Federacji Rosyjskiej wobec tych państw. Jakkolwiek trudno jest dzisiaj oceniać skuteczność Polski $\mathrm{w}$ formułowaniu nowej, unijnej polityki rosyjskiej, to wydaje się, że w dalszym ciągu partykularne interesy np. w zakresie bezpieczeństwa energetycznego, biorą górę nad podjęciem wspólnych środków antyrosyjskich. Z drugiej strony agresja Rosji na Ukrainę wymaga odpowiedzi racjonalnej, której skutki nie wiodłyby do rozniecenia konfliktu zbrojnego. Jednak kolejny raz UE pokazała, że w sprawach polityki zagranicznej - nie jest monolitem, a państwom o dużych aspiracjach nie udaje się wypracować konsensusu nie tylko we własnym gronie, ale również w gronie ich nowych partnerów.

Analizując polski jubileusz członkostwa w Unii z europejskiej perspektywy, warto zwrócić uwagę na atmosferę polityczna, która towarzyszyła akcesji 10-ciu nowych państw członkowskich do UE. Po pierwsze, z chwilą akcesji zakończył się ważny etap zmian ustrojowych w Europie Środkowej i Wschodniej. Wysiłek dyplomatyczny większości państw b. republik radzieckich i państw satelickich po 90-tym roku skoncentro- 
wał się na zasadniczej zmianie priorytetów w zakresie obronności i współpracy gospodarczej. W perspektywie zapaści ekonomicznej ZSRR państwa Europy Środkowej i Wschodniej stanęły przed mało realną perspektywą budowy regionalnego własnego układu gospodarczego lub też przyłączenia się do kształtowanych po II wojnie światowej form współpracy państw demokratycznych. Stąd kroki w kierunku integracji europejskiej w ramach Europejskiej Wspólnoty Gospodarczej/Unii Europejskiej. Dbając o swoje bezpieczeństwo, państwa podjęły wysiłek integracyjny w ramach Paktu Północnoatlantyckiego.

Nie można zapominać, iż oba procesy, determinując wysiłek lokalnych elit politycznych, w zasadniczy sposób wpłynęły na kierunki procesu transformacji ustrojowej. Jej zasadniczy cel wyznaczały doświadczenia demokratyczne państw zachodnioeuropejskich i sformułowane np. w Traktacie o Unii Europejskiej kryteria członkostwa w tej organizacji.

W tym samym czasie również państwa zachodnioeuropejskie zaczęły szukać nowych celów i modeli integracyjnych w zmienionej rzeczywistości międzynarodowej. Po pierwsze, droga do zjednoczenia w ramach EWG całego kontynentu europejskiego stanęła przed nimi otworem. Po drugie presja integracyjna była dość silna i można było odnieść wrażenie, że są potrzebne dwa, trzy ruchy by Unia została powiększona. Tak jak w Polsce i państwach wyrażających chęć akcesji do Unii trwały przygotowania do akcesji, tak również po stornie UE-15 trwały przygotowania do znaczącego powiększenia swego składu członkowskiego. Zadawane wówczas pytania brzmiały mniej więcej tak:

- czy Unia jest przygotowana na rozszerzenie?

- na jakich zasadach Unia przyjmie nowych członków?

- czy aspiranckie państwa są gotowe do akcesji?

- o ile państw członkowskich należy Unię rozszerzyć?

Traktatowy model integracji europejskiej dla powiększonego grona państw członkowskich został podpisany 13 grudnia 2007 roku w Lizbonie. Sam Traktat, jego kształt oraz zawartość były efektem kompromisu wpisanego w kryzys traktatowy związany z niepowodzeniem projektu konstytucyjnego. Opóźnienie w rozszerzeniu zdaniem Wima Koka „byłoby dużą polityczną porażką dla Europy. Pociagnęłoby to za sobą koszty zarówno dla UE, jak i dla krajów kandydujących:

- brak powiększenia jednolitego rynku, a w rezultacie niższy wzrost gospodarczy w krajach kandydujących, pozbawiłby UE korzyści ekonomicznych;

- w krajach kandydujących, osłabiłoby to bodziec dla reform, zniechęciło inwestorów zagranicznych i zmniejszyło wzrost gospodarczy;

- doprowadziłoby do politycznej destabilizacji, z potencjalnymi reperkusjami dla UE. Wzrosłoby ryzyko w rejonie Bałkanów, gdzie pokój i stabilizacja są nadal kruche;

- bez rozszerzenia UE miałaby mniejsze możliwości zwalczania zorganizowanej przestępczości, nielegalnej imigracji i terroryzmu;

- pozbawienie złudzeń obywateli w państwach kandydujących stałoby się pożywką dla euro-sceptycyzmu w UE i poza nią" (Kok, 2003).

Rocznica rozszerzenia Unii Europejskiej o państwa Europy Środkowej i Wschodniej była też przedmiotem zainteresowania i podsumowań po stronie państw zachodnioeuropejskich. Zarówno oficjalne wypowiedzi czołowych polityków europejskich, 
jak i nagłówki głównych tytułów prasy zachodnioeuropejskich podkreślały doniosłość wydarzenia i korzyści płynące dla całej Unii Europejskiej. W opracowaniu podsumowującym rozszerzenie i jego znaczenie dla Europy i dla Niemiec autorzy ekspertyzy dla Witschaftdienst podkreślają kilka wątków. Wśród nich duże znaczenie dla stabilności politycznej tej części kontynentu, które zostało przypieczętowanie akcesją do UE, a przez to dostosowaniem się do unijnych standardów. Ponadto wskazuje się na duże znaczenie jakie dla dynamiki unijnej gospodarki miało rozszerzenie. Wśród zalet autorzy opracowania wskazują na dalszą liberalizację kontaktów handlowych, otwarcie nowego rynku zamówień publicznych, modernizację napędzaną przez środki europejskie, stabilizację gospodarczą Unii (Bilanz, s. 1 i 2). W podobnym tonie wypowiada się redaktor Hanno Mussler z „Frankfurter Allgemeine Zeitung”. Co prawda we wstępie artykułu zauważa, że w stolicach państw Europy Środkowej i Wschodniej jeżdżą nowe limuzyny zamożnych europejczyków, to jednak w dalszej części tekstu wskazuje na konkretniejsze korzyści ze wschodniego rozszerzenia UE. I tak dla przykładu wskazuje na większą niż przed akcesją trudność przy osiagnięciu przez UE jednomyślności w ważnych kwestiach bieżącej polityki. Ponadto autor wskazuje na zwiększającą się zamożność wschodnich europejczyków, na zwiększającą się niezależność gospodarczą od rynków wschodnich (FAZ, 2014, s. 1-3).

Dużym wyzwaniem dla Unii, jak i dla Polski była kwestia zwalczania skutków kryzysu gospodarczego. Co prawda spowolnienie gospodarcze dla większości Polaków było jedynie znane z relacji telewizyjnych z Grecji, Hiszpanii czy Portugalii, to jednak dla polskiego rządu okres ten był ważnym etapem dla wysiłków dyplomatycznych chroniących Unię Europejską przed fragmentacją integracyjną. Kryzys ekonomiczny należy zaliczyć do tej grupy wydarzeń politycznych i gospodarczych w UE, które w dłuższej perspektywie czasu zmienią system unijny, korygując wcześniej przyjęte rozwiązania lub też zastępując obecne, nowymi mechanizmami korekty gospodarczej strefy euro. Zmiany te wpływają na państwa członkowskie, ich systemy polityczne, dokonując ich nowej hierarchizacji względem przyjętych rozwiązań konsolidujących współpracę gospodarczą. Wymagają wypracowania nowych kanałów współpracy pozwalających na koordynację szczytów gospodarczych UE, w formule państw członków strefy euro i tej szerszej w ramach 25 państw tworzących nieformalne ugrupowanie euro+. Ich analiza winna się odbywać przez pryzmat innowacji i korekcji. W zależności od rozwoju sytuacji gospodarczej i politycznej w UE sformułowana treść sprzężenia zwrotnego może mieć charakter dodatni, prowadzący w przyszłości do nowelizacji traktatów bazowych UE (Tomaszyk, 2013, s. 51).

Na gospodarcze aspekty członkostwa zwracają również uwagę autorzy rządowego raportu jubileuszowego. Wypada cieszyć się z 476 mld PLN eksportu do Unii w 2013 roku, z nadwyżki handlowej z Unią sięgającej kwoty 100 mld PLN czy też z ponad 3,5-krotnego wzrostu inwestycji zagranicznych w Polsce (Raport). Odnosząc się jednocześnie do kwestii antykryzysowych inicjatyw płynących z naszego kraju, wskazuje się na wprowadzenie możliwości bliskiej współpracy państw spoza strefy euro w pierwszym etapie unii bankowej tj. nadzorze nad sektorem bankowym. Ponadto, „Polska konsekwentnie zabiegała o wzmocnienie efektywności zarządzania gospodarczego oraz zabezpieczenie strefy euro przed kryzysami w przyszłości [...] dzięki naszym zabiegom udało się zachować otwarty charakter reform strefy euro nie 
pogłębiać podziałów w Europie. Udało się otworzyć Traktat Fiskalny na państwa spoza strefy euro" (Raport MSZ, s. 53).

\section{Podsumowanie}

Dekada polskich doświadczeń członkostwa w Unii Europejskiej pokazuje, że na gruncie krajowej polityki można określić dwa zasadnicze modele integracji, które są prezentowane przez dwie największe partie polityczne. Każda z nich zarówno Prawo i Sprawiedliwość, jak i Platforma Obywatelska RP miały możliwość praktycznej realizacji głoszonych przez liderów partyjnych tez o członkostwie Polski w UE. Różnice programowe między tymi partiami zaczęły się kreować już przy okazji prowadzonej przez nie kampanii referendalnej w sprawie akcesji Polski do Unii Europejskiej. To w tamtym czasie PiS zbudował swój program wokół siły Polski w Unii Europejskiej opartej między innymi na sile głosu w Radzie Unii Europejskiej i twardej polityce wzmacniającej interesy narodowe. Z kolei Platforma Obywatelska realizację swoich priorytetów polityki europejskiej widzi nie tylko w gronie członków Rady Unii Europejskiej, ale również poprzez skuteczny lobbing polskich spraw na etapie prelegislacyjnych konsultacji Komisji Europejskiej, lobbing w Parlamencie Europejskim, i szeroką współpracę na niedocenionych przez wielu, forach unijnej polityki. Taką chociażby możliwość daje przynależność tej partii do największej frakcji w Parlamencie Europejskim. Te dwie logiki integracyjne można ująć w kategoriach teoretycznych realizmu i liberalizmu politycznego. Istota różnic nawiązuje do znanego w literaturze dyskursu o wspólnotowej i międzyrządowej metodzie integracyjnej.

Umocnienie cech ponadnarodowych Unii należy rozpatrywać przez pryzmat poszerzania zakresu oddziaływania metody wspólnotowej, której zasadniczymi elementami są: wzmacnianie pozycji Komisji Europejskiej, decydowanie na zasadzie większości kwalifikowanej w Radzie Unii Europejskiej przy jednoczesnym poszerzeniu zakresu dziedzin, w których Parlament Europejski otrzymuje prawo współdecyzji, poszerzanie zakresu jurysdykcji Trybunału Sprawiedliwości i in. przy jednoczesnym ograniczaniu wpływu państw członkowskich na przebieg procesu integracji europejskiej. Wydaje się, że zwolennikiem tej metody integracyjnej jest Platforma Obywatelska.

Z kolei Prawo i Sprawiedliwość większych szans na polski sukces w UE upatruje w metodzie międzyrządowej. Międzyrządowe podejście będzie się tym samym koncentrowało na utrzymywaniu bądź poszerzaniu uprawnień Rady Unii Europejskiej i/lub Rady Europejskiej, przy jednoczesnym ograniczaniu roli instytucji ponadnarodowych. Państwa członkowskie, którym bliższa jest ta optyka integracji europejskiej będą uzasadniały taki kierunek reformy systemu decyzyjnego w RUE, aby wyrównywał on różnice między państwami członkowskimi, zbliżając potencjał koalicyjny każdego z nich (stąd metoda pierwiastkowa). Ponadto będą przeciwnikami poszerzania katalogu dziedzin objętych głosowaniem większością kwalifikowaną i będą starały się zwiększyć swój formalny i nieformalny wpływ na Komisję Europejską. W kontekście prawa wtórnego Unii Europejskiej i jego wpływu na system prawa krajowego, międzyrządowość będzie zakładała brak bezpośredniej skuteczności podejmowanych decyzji, które aby uzyskały moc wiążącą będą wymagały wdrożenia, implementacji do 
porząaków krajowych (np. w Polsce spór o metodę ratyfikacji paktu fiskalnego). Ponadto zwolennicy rozwiązań międzyrządowych opowiadają się za brakiem pierwszeństwa aktów normatywnych podejmowanych w ramach takiej współpracy nad prawem państw członkowskich oraz brakiem drogi sądowej rozstrzygania sporów i brakiem możliwości sądowego wymuszenia realizacji zobowiązań podjętych przez państwa.

Zbigniew Czachór, ów dynamiczny i produktywny dla polskiego dyskursu europeistycznego spór, ujmuje w kategoriach partykularyzmu i uniwersalizmu. Partykularyzm będzie się cechował oswobadzaniem się państw od kurateli i kontroli unijnych instytucji, nadmiernym eksponowaniem suwerenności narodowej i konstytucyjnych obowiązków państw, wzmacnianiu siły politycznej państw w trakcie prowadzonych negocjacji czy też odwoływaniem się do potencjału gospodarczego państw i narastaniu tendencji hegemonicznych $w$ systemie integracyjnym. $\mathrm{Z}$ kolei uniwersalizm będzie się wiązał m.in. z przywiązaniem do wspólnych zasad, pogłębianiem solidarności między narodami w poszanowaniu ich historii, kultury i tradycji, ustanowieniem wspólnego obywatelstwa, kontynuacją procesu tworzenia coraz silniejszego związku między narodami Europy (Czachór, 2014, s. 14 i 15). Autor wskazuje, że chociażby na przykładzie naszego zaangażowania w prace Konwentu Europejskiego i IGC z 2007 roku, jak również na podstawie analizy stanowisk prezentowanych przez Polskę podczas negocjacji nad WRF 2014, nasz kraj pokazał, że: chce być samodzielnym podmiotem wewnątrzunijnej gry interesów, nie zawsze interesy Polski są zgodne z interesami pozostałych aktorów integracji, sprzeciwia się postulatowi szybszego rozwoju krajów należących do „twardego jądra” UE $i$ in. (Czachór, s. 26). Polityka ta jednak mogła być odbierana jako polityka kraju utrudniającego integrację, symbol konserwatyzmu i partykularyzmu, czy też źródło kolejnych wewnętrznych antagonizmów i marginalizacji (Czachór, s. 26).

\section{Rekomendacje}

1. Formuła ujednolicania stanowisk politycznych państw Europy Środkowej i Wschodniej w ramach Grupy Wyszehradzkiej musi zostać lepiej wykorzystana. Stosowanie takich instrumentów jak regularne konsultacje premierów, ministrów spraw zagranicznych, wiceministrów ds. europejskich czy też stała współpraca Stałych Przedstawicielstw powinna być normalnym sposobem na podnoszenie efektywności polityki europejskiej tych państw członkowskich UE.

2. W dalszym ciągu ważnym elementem konsolidującym UE powinna być formuła Trójkąta Weimarskiego. Zmiana stanowiska Francji i zaangażowanie Polski w ten format unijnej współpracy może w dalszym ciągu służyć koordynacji obszaru Wspólnej Polityki Bezpieczeństwa i Obrony. W interesujący sposób może rozwijać się formuła Weimar + (Raport MSZ, s. 34).

3. W dalszym ciagu należy podnosić znaczenie Polek i Polaków pracujących w unijnych instytucjach. Pomimo tego, że ich awans odbywa się często na zasadach określonych regulaminem wewnętrznym, Polska nie wykorzystuje szansy, jaką daje korpus urzędniczy na kierowniczym szczeblu. Kapitał relacyjny w ten sposób utworzony, charakteryzuje państwa o dłuższym stażu członkowskim. Nic jednak nie stoi na przeszkodzie, by również Polska taki korzystny i wspomagający rząd 
układ personalny budowała. Niestety nie wykorzystano tej szansy po zakończonej prezydencji Polski w Radzie UE, gdy wykształcony korpus prezydencji nie został w pożądany sposób zagospodarowany na potrzeby wsparcia członkostwa Polski w UE.

4. Pomimo tego, że poparcie Polaków dla integracji europejskiej jest nadal wysokie, należy pamiętać, że część zwolenników swoje przekonanie opiera na korzystnej dla nich absorpcji środków unijnych. W sytuacji, gdy całkiem realne wydaje się zmniejszanie unijnego budżetu po 2020, należy szukać również innych argumentów przemawiających za integracją europejską. W przeciwnym razie partie populistyczne i antyunijne łatwo znajdą swój elektorat.

5. W kolejnych latach należy oczekiwać dalszej profesjonalizacji polskiego systemu koordynacji polityki europejskiej. Otwarcie się rządu na głębszą niż dotychczas współpracę z parlamentem, będzie odważnym krokiem w kierunku deliberacji europejskiej podnoszącej jakość polskiej polityki europejskiej.

6. „Nadchodzące lata będą dla Unii Europejskiej i Polski decydujące. Konieczne będzie znalezienie odpowiedzi na kluczowe pytania: w jakiej Unii chcemy być w XXI wieku? Jak odbudujemy wzajemne zaufanie między europejskimi instytucjami i obywatelami? Jaką rolę ma odgrywać Europa w świecie? Jak chcemy realizować swe interesy, kształtując zglobalizowany świat, zgodnie z naszymi wartościami? Jak zachować demokratyczny i socjalny model społeczny?

7. Polska musi współpracować z innymi państwami należącymi do UE. Powinna odgrywać aktywną i konstruktywną rolę, uwzględniając zarówno interesy Polski, jak i dobro całej Unii Europejskiej. Umacniając pozycję Polski musimy opowiadać się za dalszym poszerzaniem i pogłębianiem Unii, mając też na uwadze cały system euroatlantycki i jego rolę w zapewnianiu bezpieczeństwa europejskiego i globalnego.

8. W polskim interesie narodowym leży takie kształtowanie procesu integracji europejskiej, by czynił on UE bardziej spójną i sprawną oraz umacniał jej pozycję międzynarodową. W Unii szczególnie powinniśmy pielęgnować stosunki z sąsiadami, dużymi i małymi. W stosunkach z naszymi mniejszymi sąsiadami powinniśmy kierować się zasadą bezinteresownej życzliwości oraz uwzględniać i wspierać ich potrzeby i postulaty, co pozwoli osiągnąć Polsce status mocarstwa regionalnego.

9. Ważnym elementem polskiej strategii integracyjnej powinna być dalsza modernizacja państwa oraz ograniczanie cywilizacyjnych barier oddzielających nasz kraj od głównych państw zachodnioeuropejskich" (Fiszer, 2014, s. 4).

\section{Bibliografia}

Busch B., Grömling M. (2014), Eine Bilanz zehn Jahre nach der EU-Osterweiterung, http://www.iwkoeln.de/de/presse/gastbeitraege/beitrag/berthold-busch-und-michael-groemling-im-wirtschaftsdienst-eine-bilanz-zehn-jahre-nach-der-eu-osterweiterung-169548.

Czachór Z. (2014), Polska w Unii Europejskiej: między uniwersalizmem a partykularyzmem, w: K. Wojtaszczyk, M. Wrotkowska-Mizerska, W. Jakubowski, Polska w procesie integracji europejskiej. Dekada doświadczeń (2004-2014), Warszawa.

Fiszer J. (2014), Ekspertyza. Bilans 10 lat członkostwa Polski w Unii Europejskiej, źródło własne. 
Fiszer J., Tomaszyk M. (red.) (2013), Zarzadzanie procesem integracji i modernizacja Unii Europejskiej, ISP PAN, Warszawa.

Ilu Polaków w Brukseli, Polityka Insight, 27 kwietnia 2014, www.polityka.pl.

Polska katolicka w chrześcijańskiej Europie, Program PiS, Warszawa 2005.

Raport Ministerstwa Spraw Zagranicznych (2014), Polskie 10 lat w Unii, Warszawa.

Raport z badań CBOS (2003), Społeczne poparcie dla integracji z UE, BS/27/2003, Warszawa.

Schulz M. (PAP), Rozszerzenie UE budziło obawy, ale okazały się bezpodstawne, z Brukseli Anna Widzyk.

Schulz M., Schulz gratuluje Polsce 25-ciu wspaniałych lat po komunizmie, Komunikat prasowy Biura Prasowego Parlamentu Europejskiego, http://www.europarl.europa.eu/former_ep_presidents/president-schulz/fr-en/press/press_release_speeches/press_release/2014/2014-may/html/ schulz-congratulates-poland-on-successful-25-years-after-communism.

Semka P. (2010), Lech Kaczyński. Opowieść arcypolska, Wydawnictwo czerwone i czarne, Warszawa, na podstawie: W Izraelu czuję się jak w domu, „Rzeczpospolita” z dnia 17.05.2008.

Silna Polska w Europie, Uchwała nr 1/06/03, Rada Polityczna PiS, Warszawa 2003.

Tekst expose premiera Donalda Tuska z dnia 23.11.2007, pobrano z http://www.rp.pl/artykul/ 71439.html.

Tomaszyk M. (2012), Polskie przewodnictwo w Radzie Unii Europejskiej-próba oceny, w: Prezydencja Polski w Radzie Unii Europejskiej, red. J. Fiszer, Wydawnictwo Naukowe ISP PAN, Warszawa.

Tomaszyk M. (2012), Wzmocniona legitymacja demokratyczna Unii Europejskiej - rozważania w kontekście inicjatywy obywatelskiej, nowych zasad wyborów do Parlamentu Europejskiego i udziału parlamentów krajowych w procesie integracji europejskiej, „Myśl Ekonomiczna i Polityczna", nr 3(38), Warszawa, s. 122-154.

Warzecha Ł. (2010), Lech Kaczyński - ostatni wywiad, Prószyński i S-ka, Warszawa.

\section{Streszczenie}

Dekada polskich doświadczeń członkostwa w Unii Europejskiej pokazuje, że na gruncie krajowej polityki można określić dwa zasadnicze modele integracji, które są prezentowane przez dwie największe partie polityczne. Każda z nich zarówno Prawo i Sprawiedliwość, jak i Platforma Obywatelska RP miały możliwość praktycznej realizacji głoszonych przez liderów partyjnych tez o członkostwie Polski w UE. Różnice programowe między tymi partiami zaczęły się kreować już przy okazji prowadzonej przez nie kampanii referendalnej w sprawie akcesji Polski do Unii Europejskiej. To w tamtym czasie PiS zbudował swój program wokół siły Polski w Unii Europejskiej opartej między innymi na sile głosu w Radzie Unii Europejskiej i twardej polityce wzmacniającej interesy narodowe. Z kolei Platforma Obywatelska realizację swoich priorytetów polityki europejskiej widzi nie tylko w gronie członków Rady Unii Europejskiej, ale również poprzez skuteczny lobbing polskich spraw na etapie prelegislacyjnych konsultacji Komisji Europejskiej, lobbing w Parlamencie Europejskim i szeroką współpracę na niedocenionych przez wielu, forach unijnej polityki. Celem opracowania było wskazanie najważniejszych, zdaniem autora, wydarzeń charakteryzujących członkostwo Polski w Unii Europejskiej. Autor dokonał ich systematyzacji, opisu, a także podziału na wydarzenia europejskie mające wpływ na bieg spraw krajowych i na te krajowe, które cechowały polską dyplomację europejską w ostatniej dekadzie. Autor wskazuje cechy charakterystyczne dwóch dyskursów o polskiej polityce europejskiej, które już od referendum akcesyjnego, przez kolejne lata członkostwa w UE anga- 
żują uwagę Polek i Polaków wokół spraw unijnych. Na tej podstawie zostały nakreślone kierunki polskiej polityki europejskiej w perspektywie kolejnych lat członkostwa w UE.

Słowa kluczowe: Unia Europejska, członkostwo Polski w UE

\title{
Ten years of Poland's membership of the European Union - an attempt at assessment from the point of view of political science
}

\begin{abstract}
Summary
The decade of Polish membership of the European Union has shown two fundamental models of integration presented in domestic policy by the two leading political parties. Both Law and Justice (PiS) and Civic Platform (PO) have had the opportunity to implement in practice their leaders' declarations about Poland's EU membership. Political differences between the two parties emerged as early as the referendum on Poland's accession to the European Union. At that time, the PiS party constructed its political platform around the idea of a strong Poland whose position would result, among other things, from its power in the Council of the European Union and a hard-line policy strengthening Poland's international interests. The PO party, in turn, saw the implementation of its priorities in European policy as a result of operating not only in the circle of members of the Council of the European Union but also by exercising efficient lobbying activities at the pre-legislation stage of consultation in the European Commission, in the European Parliament and extensive cooperation on various, frequently underestimated, forums of EU politics. This paper aims to indicate the most important characteristics of Poland's EU membership as seen by the author. He categorises, describes and divides them into those European events that influenced domestic affairs, and those domestic events that determined Polish European diplomacy over the last decade. The author indicates the characteristic features of the two discourses about Polish European policy that have been attracting the attention of Poles to EU matters since the accession referendum. On this basis, the future directions of Polish European policy are outlined for further years of EU membership.
\end{abstract}

Key words: Polish European policy, PO and PiS towards European integration, assessment of Poland's decade in the EU 